\title{
Article
}

\section{Drug calculations for urinary incontinence in women}

\author{
Nuttall, Dilyse \\ Available at http://clok.uclan.ac.uk/21246/ \\ Nuttall, Dilyse ORCID: 0000-0002-0561-5229 (2015) Drug calculations for \\ urinary incontinence in women. Nurse Prescribing, 13 (10). pp. 484-485. ISSN \\ 2052-2924
}

It is advisable to refer to the publisher's version if you intend to cite from the work.

For more information about UCLan's research in this area go to

http://www.uclan.ac.uk/researchgroups/ and search for < name of research Group>.

For information about Research generally at UCLan please go to http://www.uclan.ac.uk/research/

All outputs in CLoK are protected by Intellectual Property Rights law, including Copyright law. Copyright, IPR and Moral Rights for the works on this site are retained by the individual authors and/or other copyright owners. Terms and conditions for use of this material are defined in the policies page.

\section{CLoK}

Central Lancashire online Knowledge www.clok.uclan.ac.uk

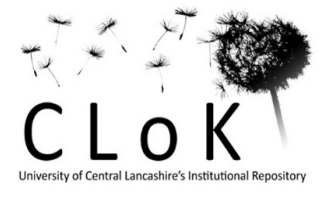




\section{Calculation Skills: Urinary Incontinence in Women}

An estimated 3 - 6 million people are affected by urinary incontinence in the UK, with the condition being more common in women (NHS Choices, 2015). Causes of urinary incontinence vary but urge incontinence is usually due to over-activity of the bladder's detrusor muscles, whereas stress incontinence is caused by muscle damage or weakness (NHS Choices, 2015). The management of urinary incontinence may require drug treatment in conjunction with pelvic floor and bladder training exercises (Joint Formulary Committee, 2015). The choice of treatment should be determined following thorough assessment, which takes into account relevant factors such as the type of urinary incontinence, the patient's age, other existing conditions and their associated treatments (NICE, 2013).

Fiona is a 63 year old retired accountant and has been suffering from urgency of micturition for 5 months. She has recently been diagnosed with 'over active bladder' (OAB).

\section{Question A}

Archie's current dose of warfarin is $4 \mathrm{mg}$ daily. Warfarin tablets are available in strengths of $1 \mathrm{mg}$, 3mg and $5 \mathrm{mg}$.

(i) Calculate the combination of tablets needed to enable him to take his daily dose of $4 \mathrm{mg}$ of warfarin.

(ii) Calculate the number of tablets that will need to be prescribed to enable Archie to maintain the daily dose of $4 \mathrm{mg}$ for the six weeks between his appointments.

\section{Question B}

At Archie's next monitoring appointment, his INR has reduced. It is decided that the daily dose of Warfarin should be temporarily increased to $6 \mathrm{mg}$ for two days.

What would be simplest way for this to be prescribed if tablets are available in strengths of $1 \mathrm{mg}, 3 \mathrm{mg}$ and $5 \mathrm{mg}$ ?

Question C Incontinence products

Half-life can be defined as 'the time required for the concentration of the drug in the plasma to decrease by half of its initial valuue' (Fittock, Alder, Astles et al, 2011). Warfarin has a half-life of between 20 and 60 hours.

Calculate the mean (standard average) half-life of warfarin?

\section{Question D}


Miller, Jones, Sullivan et al (2009) suggest that up to $92 \%$ of the orally administered dose of warfarin can be found in the urine, in the form of metabolites.

Using this maximum of $92 \%$, if a dose of $7 \mathrm{mg}$ Warfarin is given, how many milligrams WILL NOT be present in the urine?

\section{$\underline{\text { References }}$}

Joint Formulary Committee (2015) BNF 69, London: BMJ Group \& Pharmaceutical Press

NHS Choices (2015) Urinary Incontinence, available on-line at: http://www.nhs.uk/conditions/incontinence-urinary/pages/introduction.aspx

National Institute for Health \& Care Excellence (2013) Urinary Incontinence: The Management of Urinary Incontinence in Women, CG171, London: NICE

\section{Calculation Answers}

Question A

Calculate the combination of tablets needed to enable him to take his daily dose of $4 \mathrm{mg}$ of warfarin.

In order to take a daily dose of warfarin $4 \mathrm{mg}$ :

$1 \times 1 \mathrm{mg}$ tablet $+1 \times 3 \mathrm{mg}$ tablet $=4 \mathrm{mg}$

Calculate the number of tablets that will need to be prescribed to enable Archie to maintain the daily dose of $4 \mathrm{mg}$ for the six weeks between his appointments.

You have established that for one day's treatment, one $1 \mathrm{mg}$ tablet and one $3 \mathrm{mg}$ tablet will be needed.

Next you need to calculate how many days treatment will be required:

1 week $=7$ days

6 weeks $=6 \times 7$ days

$6 \times 7=42$ day's treatment

In order to determine how many tablets will be needed for the 42 days of treatment, the amount of tablets required for one day's treatment must be multiplied by the total number of days of treatment needed:

Remember that as the dose is achieved through using two strengths of tablet, you will need to prescribe two strengths of tablet. Therefore, you need to specify how many of each tablet strength will be needed:

Dilyse Nuttall 
3mg tablet: 1 daily $\times 42$ days $=42$ tablets

$1 \mathrm{mg}$ tablet: 1 daily $\times 42$ days $=42$ tablets

42 warfarin $3 \mathrm{mg}$ tablets and 42 warfarin $1 \mathrm{mg}$ tablets will be required. A total of 84 tablets will be required.

\section{Question B}

What would be simplest way for this to be prescribed if tablets are available in strengths of $1 \mathrm{mg}, 3 \mathrm{mg}$ and $5 \mathrm{mg}$ ?

In order to achieve a dose of $6 \mathrm{mg}$ of warfarin from the tablet strengths available, a combination of two tablets will be needed:

Option $1: 1 \mathrm{mg}+5 \mathrm{mg}=6 \mathrm{mg}$

Or

Option 2: $3 \mathrm{mg} \times 2=6 \mathrm{mg}$

When writing a prescription, option 2 would be the preferred option in terms of simplicity for the prescriber (and potentially easier for the patient to understand). If option 1 was used, although not incorrect, it would be necessary to provide information on strength, dose, dose frequency, preparation and quantity for both sets of tablets prescribed.

\section{Question C}

Calculate the mean (standard average) half-life of warfarin?

Mean is calculated by adding the known values and dividing this total by the number of known values:

The known values are: 20 and 60 hours, so $20+60=80$

The number of known values is two (20 hours and 60 hours).

To calculate the mean:

$\underline{20+60}=\underline{80}=40$

$$
22
$$

The mean half-life of warfarin is 40 hours

\section{Question D}


If a dose of 7mg Warfarin is given, how many milligrams WILL NOT be present in the urine? First it is necessary to determine what percentage of the drug is not present in the urine: $100 \%-92 \%=8 \%$ $8 \%$ of the drug will not be present in the urine.

Then you can calculate what this equates to in milligrams:

$100 \%$ of the dose is $7 \mathrm{mg}$

$1 \%$ of the $7 \mathrm{mg}$ dose can be calculated by dividing the dose by $100: 7 \div 100=0.07 \mathrm{mg}$ $8 \%$ of the $7 \mathrm{mg}$ dose can be calculated by multiplying the amount of drug in $1 \%$ by 8 : $0.07 \times 8=0.56 \mathrm{mg}$ The amount of drug not present in the urine is $0.56 \mathrm{mg}$ 